\title{
下腿部での脈波同期併用二次元 Time of Flight 法 MR-Angiography について Gated 2D Time of Flight Method in MR-Angiography of the Lower Leg
}

\author{
埼玉医科大学総合医療センター 放射線部

○松田 恵雄 永井 敦志 \\ (Shigeo Matsuda) (Atsusi Nagai) \\ 桜井 靖雄
(Yasuo Sakurai) \\ 千葉 亮一 \\ (Ryouiti Chiba)
}

【目的】下腿部の二次元 Time of Flight MR-Angiography は、血流が遅い為十分な Inflow 効果が得られず、 血流信号と実質部のコントラストが付きにくい。今回我々は、心電図同期ではなく脈波同期を併用し 血流信号の改善を試みたので報告する。一般的に心電図同期が用いられる理由として、最大血流速の 心時相に Trigger 遅延を設定するため、脈波同期ではシステムの制約により最大血流速の心時相撮像が 不可能な事による。本検討では、最大血流速となる心時相が必ずしも、最大血流信号を得られる心時相 では無いとの観点から、脈波同期の併用で十分な血流信号改善が行えるとの確認を行っている。

【方法】使用機種は、GE 社製 1.5T 超伝導型 MRI Signa Horizon Lx Ver 8.0.4 で、Coil は Phased Array Type の体幹部用対向型 Surface Coil の Torso Coilo 撮像 Sequence は、 $\mathrm{k}$-space segmentation を併用 した高速 Gradient Echo 法（FCARD）を用いる。ボランティアにおいて、安静下で脈波同期を用いた Cine Phase Contrast 法による血流速の測定 (16Phase)を行った後、各 Phase と同一心時相の Trigger 遅延を設定した同期併用のTOF 法において複数の原画像を撮像し、画像上て血流の信号值を測定する ことで、血流信号が最大となる Trigger 遅延を同定する。脈波同期のみでは最大血流速における血流の 信号測定が不可能なため、心電図同期併用で同様の測定を行い、血流信号が最大となる Trigger 遅延を 同定する。なお予備実験から、View per Segment を16に設定した場合、実質部と血流のコントラスト が最大となることを確認し、View per Segment は 16 とした。ただし、View per Segment 16 に 設定すると信号収集時間の延長が起こるため、この延長が血流信号の各 Trigger 遅延における变化 パターンと関与していない事を確認する目的で、View per Segment を2に設定した同様の測定を行い、 血流信号との非関連を確認した。

【結果】脈波同期併用時換算で心周期の $24 \sim 60 \%$ 遅延時心時相で最大血流信号が得られた。この心時相は 特に負の血流の直後である場合が多かった。最大血流信号を得られる心時相は必ずしも最大血流速を 持つた心時相ではないことが示唆された。血流速 (平均) と最大血流信号を示す心時相との関連を、 直接相関する事は不可能であったが、心拍数と何らかの関係があることが示晙された。

一般的な血流速パターンを持つ下肢の二次元Time of Flight MR-Angiographyにおいては、最適な Trigger 遅延が System 最短遜延時間より長いため脈波同期で十分改善が行える。簡易性・安全性から 脈波同期はより有用と考えられる。View per Segment と血流信号パターンとの関連は得られなかった。

【結語】本法において最大血流信号を得られるTrigger 遅延は、最大血流速となる心時相では無いため、 脈波同期の併用で十分な血流信号の改善が可能であった。

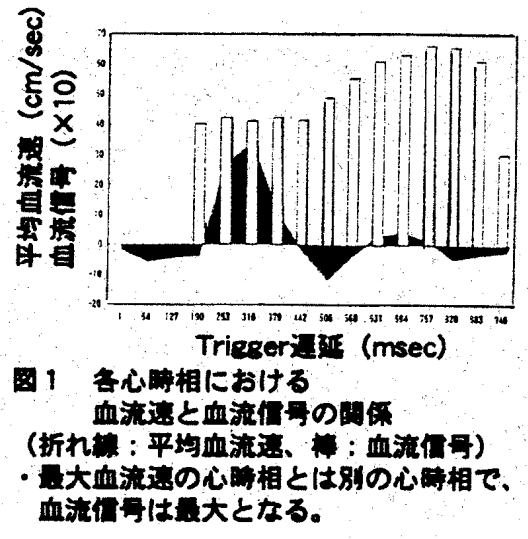

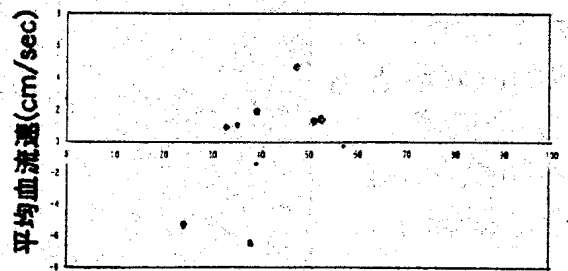

大血拣を示す心睛相 (\%)

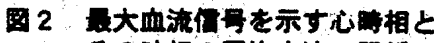
その㭙相の平均血流の保

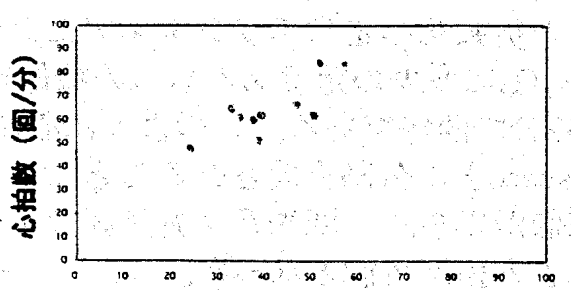

大血流を示す心时相 (\%)

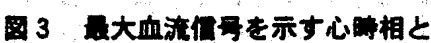
心拍数の成保 